[XLeP]

\title{
Extension of the astronomically calibrated (polarity) time scale to the Miocene/Pliocene boundary
}

\author{
F.J. Hilgen \\ Department of Geology, Institute of Earth Sciences, Budapestlaan 4, 3584 CD Utrecht, The Netherlands
}

Received April 22, 1991, revised version accepted August 14, 1991

\begin{abstract}
The early Pleistocene to late Pliocene astronomically calibrated tıme scale of Shackleton et al. [1] and Hilgen [2] 1s extended to the Miocene/Pliocene boundary This is done by correlating the detaled record of $\mathrm{CaCO}_{3}$ cycles in the Trubi and the lower part of the overlying Narbone Formation (Rossello composite section, Sicily) to the astronomical record, using (1) inferred phase relations between these $\mathrm{CaCO}_{3}$ cycles and the corresponding orbital cycles of precession and eccentricity, and (2) calibration points provided by the previously established astronomical calıbration of sapropelitic layers which occur in the topmost part of the $\mathrm{CaCO}_{3}$ record [2]

This correlation allows all small-scale $\mathrm{CaCO}_{3}$ cycles in the Rossello composite section to be coded after the correlative precession peak and to be dated astronomically with an accuracy of $1 \mathrm{ky}$ In combination with the available high-resolution magnetostratıgraphy, it further allows the construction of an astronomically calibrated Geomagnetic Polanty Time Scale for the major part of the Gilbert and Gauss Chrons This new time scale gives ages for the reversal boundaries of the Kaena (3 04-311 Ma) and Mammoth (3 22-3 $33 \mathrm{Ma}$ ), the Glbert/Gauss Chron boundary (3 $58 \mathrm{Ma}$ ), and the reversal boundartes of the Cochitı (4 18-4.29 Ma), Nunivak (4 48-4.62 Ma), Sidufjall (4 80-489 Ma) and Thvera (4 98-5 23 Ma) These ages are significantly older than the ages given by conventional tıme scales Age discrepancies gradually increase with increasing age the age of $532 \mathrm{Ma}$ for the Miocene/Plocene boundary, as defined by the base of the Trubı on Sicily, is almost $05 \mathrm{~m}$ y ( $95 \%$ ) older than the presently accepted age of $486 \mathrm{Ma}[3]$

These considerable discrepancies with the conventional time scale can either be explained by an (consistent) error in the decay constants used in $\mathrm{K} / \mathrm{Ar}$ radiometric datıng or, more likely, by diffusional loss of radiogentc argon
\end{abstract}

\section{Introduction}

Astronomical calibration of clımatic proxy records provides an alternative method to construct (polarity) time scales which, in principle, have a higher resolution and are more accurate than conventıonal time scales based on linear interpolation between radiometrically dated calıbration points in marıne anomaly sequences (e.g. [4]). This astronomical calibration is now firmly established for the last 700,000 years [5-7]. Initial attempts to extend this time scale to the early Pleistocene late Pliocene yielded ages for geomagnetic reversal boundaries that were essentially consistent with the radiometric datings [8-10]. However, results of recent studies indicate that these radiometric ages are consistently too young by $5-7 \%[1,2]$. At present, this alternatively astronomically calibrated (polarity) tıme scale extends back to $3.0 \mathrm{Ma}$ (late Gauss).
To accomplısh this new tıme scale, Hilgen [2] correlated the characteristic cyclic pattern of Pliocene-Pleistocene sapropels in marine sequences from southern Italy to the astronomical record using inferred phase relations between these sedimentary (= sapropel) cycles and the orbital cycles of precession and eccentricity. (Sapropel is used here to designate brownish coloured, often well-laminated, discrete layers relatively enriched in organic carbon. We refrained from using the redefinitıon proposed by Kidd et al. [11] because their (lower) limit of $>2 \%$ organic carbon is rather arbitrarily chosen and disregards the basic and, from a paleoenvironmental point of view, more important similarities between these layers. Our use is similar to the original meanıng of this term introduced by Olausson [12]). It was further anticipated that this time scale could be extended back to the Mrocene/Pliocene boundary using the $\mathrm{CaCO}_{3}$ cycles of the Trubi Formation on Siclly. 
Like the sapropels, these $\mathrm{CaCO}_{3}$ cycles are connected with the Earth's orbital cycles [13,14]. Moreover, they are supposedly underlain by simılar climatic oscillations held responsible for sapropel formation $[13,15]$, 1.e., dominantly precession forced variations in the intensity of the monsoonal system and circum-Mediterranean clımate [16-18].

Magnetostratigraphic calibration and subsequent spectral analysis of a high-resolution $\mathrm{CaCO}_{3}$ record of the Trubi yielded significant peaks in the orbital frequency bands of the spectrum [14]. Nevertheless, these peaks showed a remarkably consistent shift to slightly higher frequencies than those of the supposedly corresponding orbital cycles This shift could only be explained by assumıng that ages assigned to polarity reversals in the conventional Geomagnetıc Polarity Time Scales lack sufficient precision. Consequently, Hilgen and Langereıs [14] presented an alternatıve Geomagnetic Polarity Time Scale for the major part of the Gilbert and Gauss Chrons by extrapolating an average quasi-period of $21.7 \mathrm{ky}$ of the precession cycle [19] being the periodicity of small-scale $\mathrm{CaCO}_{3}$ cycles in the Trubı. The radiometrıc age of $3.40 \mathrm{Ma}$ for the Gilbert/Gauss Chron boundary [20] was employed as fixed reference point The astronomically calibrated time scale of Hilgen [2] was provisionally extended to the Mrocene-Plocene boundary by adjusting the tıme scale of Hilgen and Langereis [14] for the observed age discrepancy of $180 \mathrm{ky}$ for the mutually dated reversal boundary, the upper Kaena [2].

However, this procedure can only be considered preliminary for several reasons. In the first place, the inferred average penodicity of $21.7 \mathrm{ky}$ for the precession cycle may not be representative for the time interval under consideration. Secondly, the exact number of small-scale $\mathrm{CaCO}_{3}$ cycles in the Trubi is still uncertain due to the sometımes problematic identification of indıvidual small-scale cycles in $\mathrm{CaCO}_{3}$ maxima of largerscale, eccentricity related cycles (see [14]). Therefore, the ages provided by Hilgen [2] represent only a fair approximation of the true astronomical age of these small-scale cycles and, hence, of the geomagnetic reversal boundaries.

In the present paper, the exact calibration of the sedimentary cycles in the Trubi to the astronomical record is discussed in detail to determine the age of the individual sedımentary cycles as well as of the reversal boundaries as accurately as possible For this purpose, we used the new astronomical solution which is considered accurate in the time domain over the last $5.0 \mathrm{Ma}$ [21].

\section{Sections and lithology}

The lithostratıgraphic term Trub1 is commonly used to denote the characteristic, whitish coloured marls of the lower Pliocene on Sicily. A striking feature of these Trubi marls is the pronounced cyclic bedding on a different scale. Small-scale $\mathrm{CaCO}_{3}$ cycles are quadripartite and display greywhite(I)-beige-white(II) colour alternations. The grey and, especially, beige layers represent the less indurated, $\mathrm{CaCO}_{3}$-poor marls [13-15] These small-scale cycles have been individually numbered from the base of the Trubi upward [14]. Thus numbering could be continued in the (lower part of the) overlying Narbone Formation in which sapropelitic layers first appear. These sapropels are intercalated in the grey marl beds of the small-scale $\mathrm{CaCO}_{3}$ cycles. The average thickness of the small-scale $\mathrm{CaCO}_{3}$ cycles is approximately one meter. A small number of cycles, however, is significantly thicker. These cycles are considered to contain an extra cycle, which lacks sedimentary expression [14]. The exceptional thickness of these cycles remains confined to one of the white marl beds in these cycles

Larger-scale $\mathrm{CaCO}_{3}$ cycles can be distınguished on the basis of the cyclic recurrence of relatively thick, indurated and $\mathrm{CaCO}_{3}$-rich intervals. The expression of the small-scale, quadripartite cycles in these intervals is less obvious and the identification of individual small-scale cycles is more difficult. Both the small-scale as well as the largerscale $\mathrm{CaCO}_{3}$ cycles are linked to variations in the Earth's orbit [13,14]: small-scale $\mathrm{CaCO}_{3}$ cycles are related to precession and the larger-scale cycles to variations in eccentricity. In addition, some indication was found for obliquity related variations in $\mathrm{CaCO}_{3} \%$, but these variations are not directly relevant to the present study.

In this paper, the Rossello composite section of Hilgen [13] 1s used. This composite section is composed of the Eraclea Minoa, Punta di Marata, Punta Grande and Punta Piccola subsections (Figs. 1 and 2) and has been constructed using high-reso- 


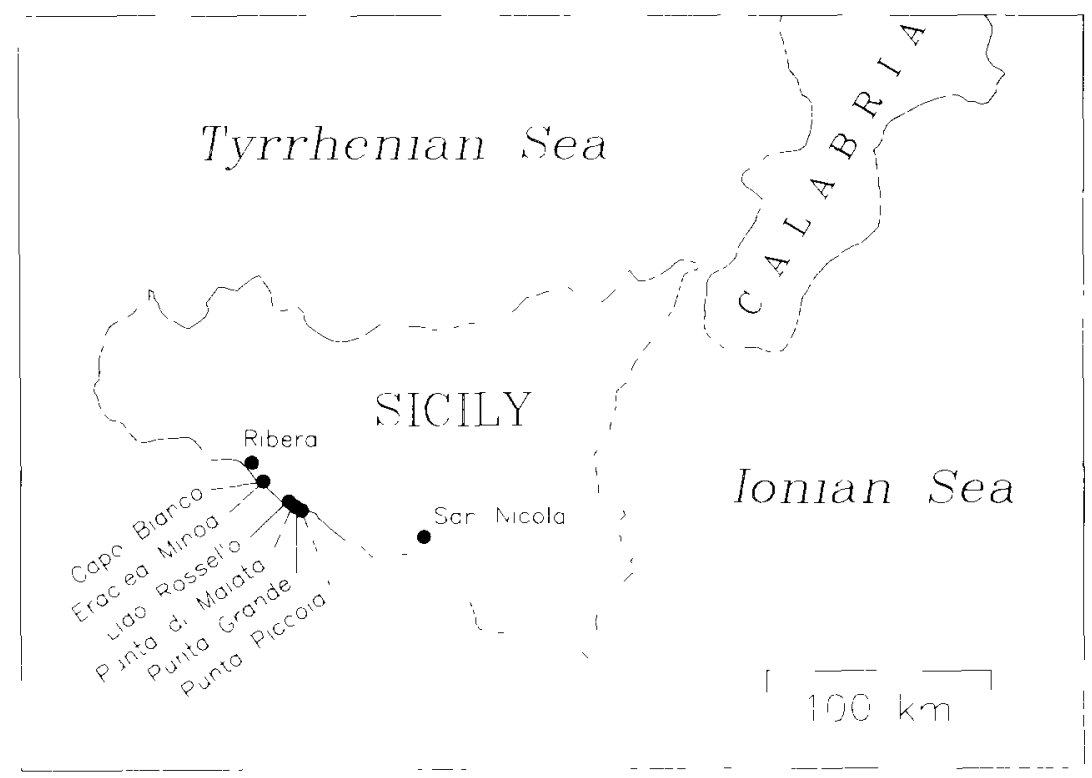

Fig 1 Locations of sections

lution cyclostratigraphic ('bed-to-bed') correlations between subsections. The Eraclea Minoa and Punta di Maiata subsections were correlated using the pronounced beige layer of cycle 24 in combination with the white marlbed, which contains white 11 of cycle 25 and grey and white I of cycle 26. The former occurs on top of the prominent interval which contains the extra-ordinary thick cycles 21 and 22, and cycle 23 of normal thickness. The correlation between the Punta di Maiata and Punta Grande subsections is based on the whitısh marl bed which contains white II of cycle 68 and grey and white I of cycle 69. Finally, the Punta Grande and Punta Piccola subsections were correlated on the basis of the white marl bed which comprises white II of cycle 77 and grey and white I of cycle 78 . The characteristic thickness and colour patterns of the cyclic bedding were verified in a number of parallel sections (Fig. 2) with the purpose of excluding stratigraphic complications present in time equivalent sections of the Rossello composite [22-24]. These parallel sections confirm that the Rossello composite section contains an uninterrupted, relatively undisturbed sequence of the Trubi and the lower part of the Narbone Formation. To fully appreciate the quality, and thus the significance, of this composite section, it should be realized that (1) all sections are excellently exposed; (2) the marls are tectoncally only slightly disturbed (with the exception of Monte San Nicola), whereas the cyclic bedding is extremely helpful in tracing faults which otherwise might upset the stratigraphic continuity, and (3) the between-section cyclostratigraphic correlations are unambiguous and are confirmed by both magnetostratigraphic and biostratıgraphic correlattions (Fig. 2).

For this Rossello composite section, both a high-quality magnetostratigraphy and planktonıc foraminiferal biostratigraphy (with a sample resolution of $\pm 10 \mathrm{ky}$ ) as well as a detailed $\mathrm{CaCO}_{3}$ record (sample resolution $\pm 5 \mathrm{ky}$ ) have been established [3,14,25-27]. The polarity sequence revealed that the composite ranges from the lower reversed subchron(ozone) of the Gilbert into the lower reversed subchron(ozone) of the Matuyama Chron [27].

\section{Astronomical calibration of the Trubi}

Two conditions must be met before the Trubi sequence can be calibrated accurately to the astronomical record. Firstly, the phase relations between the $\mathrm{CaCO}_{3}$ cycles and the corresponding astronomical cycles of precession and eccentricity must be known. Secondly, the astronomical 


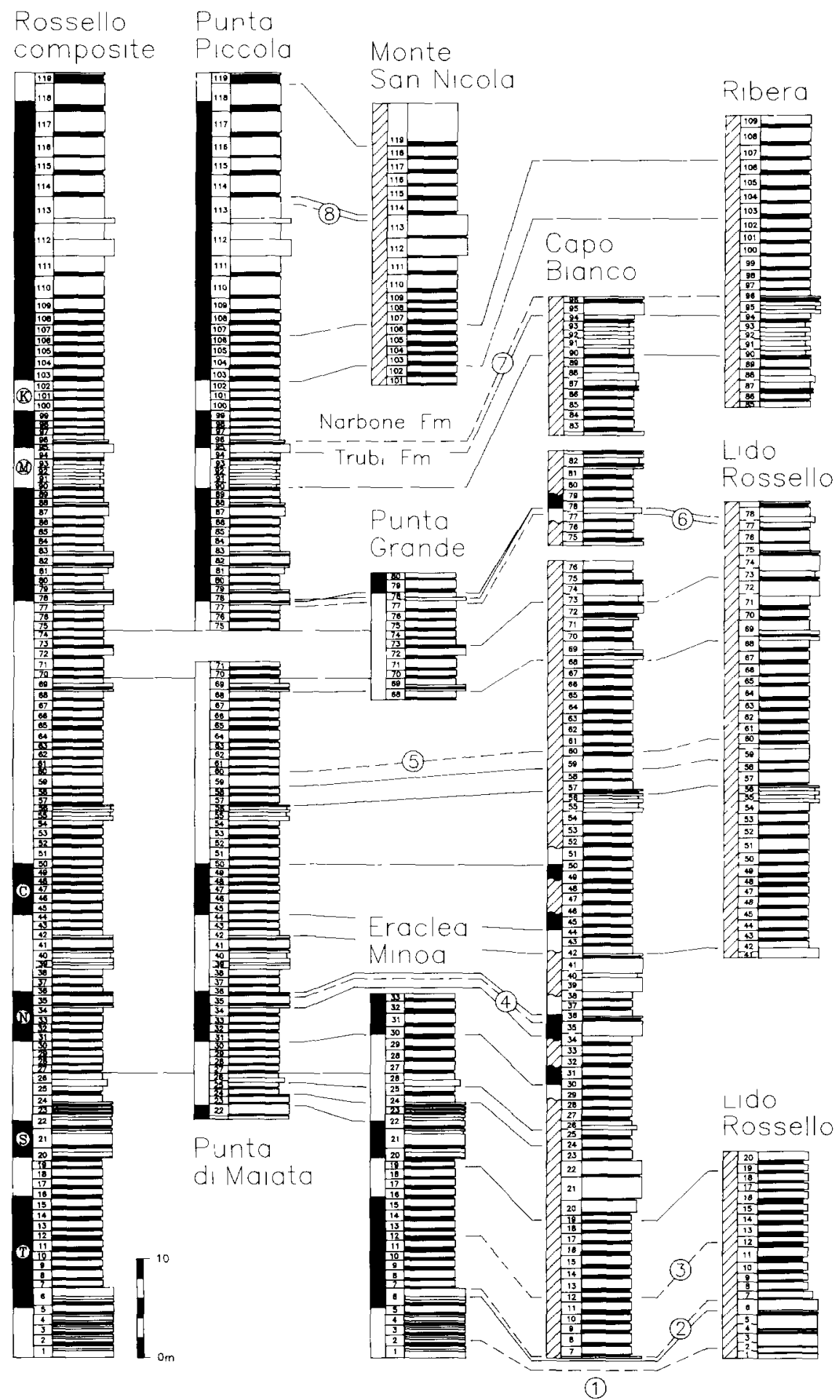

Fig 2 Review of sections in the Trubı and lower part of the Narbone Formation on southern Sicily Solıd lines mark magnetostratıgraphic and the most obvious cyclostratıgraphic correlations Dashed lines mark biostratıgraphic correlations $1=$ bottom of the Sphaeroidinellopsis acme, $2=$ top of the Sphaeroidinellopsis acme, $3=\mathrm{first}$ common occurrence of $G$ margaritae, $4=$ first occurrence of $G$ puncticulata, $5=$ last common occurrence of $G$ margartae, $6=$ first occurrence of $G$ crassaformis, $7=$ last occurrence of Sphaerotdinellopsis seminulina, and $8=$ first occurrence of $N$ atlantica. Biostratigraphic and magnetostratigraphe data based on Hilgen and Langereıs [3], Zachariasse et al. [25,26] and Langereis and Hilgen [27] and partly on unpublıshed data 
calıbration of the Trubı would be strongly fac1ltated by a calibration point which is already tied to the astronomical record.

With respect to the first condition, phase relatıons between sedımentary and astronomical cycles have already been establıshed for sapropels. These phase relations were determined by correlating late Quaternary sapropels in the Mediterranean to the new astronomical solution [2]. This correlation reveals that individual sapropels correspond to minımum peak values of the precession index. while small- and large-scale sapropel clusters correspond to eccentricity maxima connected with the 100 and $400 \mathrm{ky}$ eccentricity cycles, respectively. In addition, the sequential relationshıps between these sapropel cycles and the $\mathrm{CaCO}_{3}$ cycles could be established in the Punta Piccola subsection of the Rossello composite in which both types of sedimentary cycles co-occur. Field observations revealed that individual sapropels correspond to the grey marl beds in the small-scale $\mathrm{CaCO}_{3}$ cycles and that sapropel clusters correspond to $\mathrm{CaCO}_{3}$ minıma in the larger-scale cycles. Consequently, the following phase relations between the $\mathrm{CaCO}_{3}$ cycles and the astronomical cycles can be inferred:

Grey marl beds in the small-scale, precession related $\mathrm{CaCO}_{3}$ cycles correspond to minimum peak values of the precession index; and

$\mathrm{CaCO}_{3}$ minima of the larger-scale, eccentricity related cycles correspond to eccentricity maxima, or more correctly to maximum amplitude variations of the precession index related to the eccentricity modulation of precession.

The second condition, i.e, the necessary fixed calibration point with respect to the astronomical record, is more easily fulfilled because the lowermost sapropels in the Narbone part of the Rossello composite have already been astronomically calibrated [2]. These sapropels coincide with the topmost part of our $\mathrm{CaCO}_{3}$ record.

\subsection{Calibration of the larger-scale $\mathrm{CaCO}_{3}$ cycles to eccentricity}

A first-order astronomical calibration of the Trub1 is established by correlatıng the largest-scale $\mathrm{CaCO}_{3}$ maxima connected with the $400 \mathrm{ky} \mathrm{ec}-$ centricity cycle to the astronomical record. These $400 \mathrm{ky} \mathrm{CaCO}_{3}$ maxima can easily be recognızed in the field by the regular recurrence of extraordinary thick and indurated marly intervals which encompass the small-scale cycles 1-6, 20-23, 38$42,55-56,73-75$ and $95-96$ of the Trubı. A next maximum is distınguishable in the upper (Narbone) part of the Rossello composite and includes the cycles 112 and 113 (F1g. 3). The thus defined largest-scale $\mathrm{CaCO}_{3}$ cycles contain 17, 19 , $14,19,21$ and 17 small-scale cycles, if we consider the top of the indurated intervals to delimit these cycles. The average number of 18 is consistent with our assumption that these cycles mirror the $400 \mathrm{ky}$ (or more precisely $413 \mathrm{ky}$ ) eccentricity cycle. This astronomical cycle should correspond to 19 precession cycles, if $21.7 \mathrm{ky}$ [19] is taken as an average periodicity for precession. Extraordinary thick small-scale cycles are supposed to contain an extra cycle, and may well account for the observed discrepancy-18 versus 19 -in the number of precession (related) cycles.

To further illustrate these $400 \mathrm{ky} \mathrm{CaCO}_{3}$ cycles, we applied a moving average on the total $\mathrm{CaCO}_{3}$ record of the Trub1. A 20-point moving average was used to smooth variations in $\mathrm{CaCO}_{3} \%$ connected with both the small-scale, precession related cycles as well as the larger-scale $\mathrm{CaCO}_{3}$ cycles linked to the 100 ky eccentricity cycle. The filtered record clearly reveals the successive $400 \mathrm{ky}$ $\mathrm{CaCO}_{3}$ cycles (Fig. 3). Only the pattern between the fifth and sixth $\mathrm{CaCO}_{3}$ maximum, as counted from the base of the Trubi, is slightly complicated. This is probably caused by a strong overprint of $100 \mathrm{ky}$ variations in $\mathrm{CaCO}_{3} \%$. The reflection of this $100 \mathrm{ky}$ cycle is clearly revealed if we use a 8-point instead of a 20 -point moving average ( $F_{1} g$. 3 ). This moving average only eliminates the expression of the small-scale, precession related cycles.

Using the inferred phase relations between the $\mathrm{CaCO}_{3}$ and astronomical cycles in combination with the fixed astronomical calibration provided by the sapropelitic layers, the largest-scale $\mathrm{CaCO}_{3}$ maxima can be correlated to successive $400 \mathrm{ky}$ eccentricity minıma in the astronomical record (F1g. 3). This correlation yields ages of 2.81, 3.21, $3.67,4.07$ (or 3.99), 4.38,4.82 and 5.25 Ma for these $\mathrm{CaCO}_{3}$ maxima and can further be employed to correlate the distinct $100 \mathrm{ky} \mathrm{CaCO}_{3}$ maxima to $100 \mathrm{ky}$ eccentricity minıma (Fıg. 3). The latter correlation in addition provides an ex- 


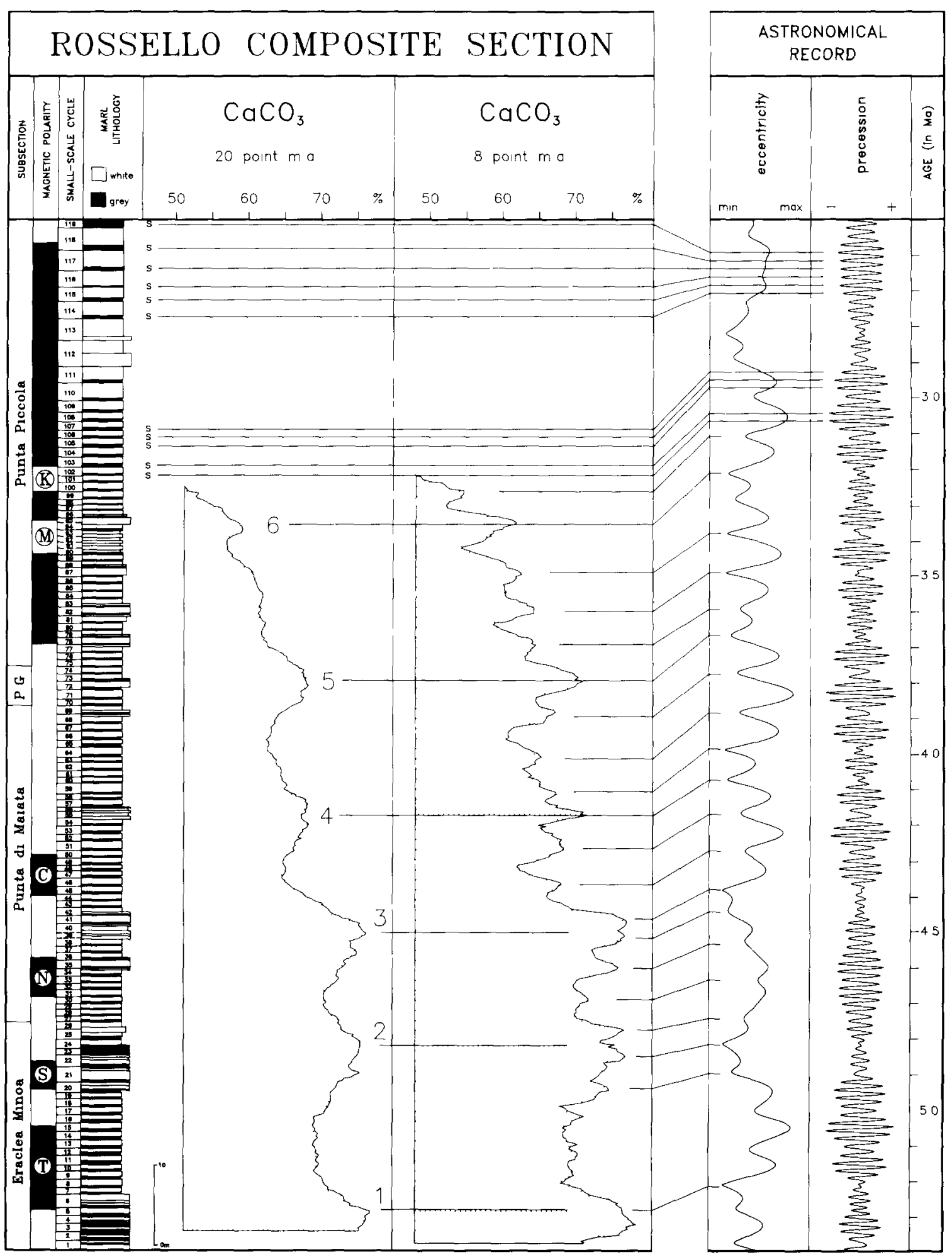

Fig 3 Correlation of $\mathrm{CaCO}_{3}$ maxima in the larger-scale cycles of the Trubı in the Rossello composite section to eccentricity minuma in the astronomical record Successive largest-scale maxima are numbered 1 to 6 from the base of the section upward Sapropels in the uppermost, Narbone part of the section are marked with an $s$ and provide fixed calibration points with the astronomical record [2] Magnetostratigraphy based on Hilgen and Langereıs [3], Zacharıasse et al [25,26] and Langereis and Hilgen [27] The astronomical record is based on the new solution of Berger and Loutre [21]. 


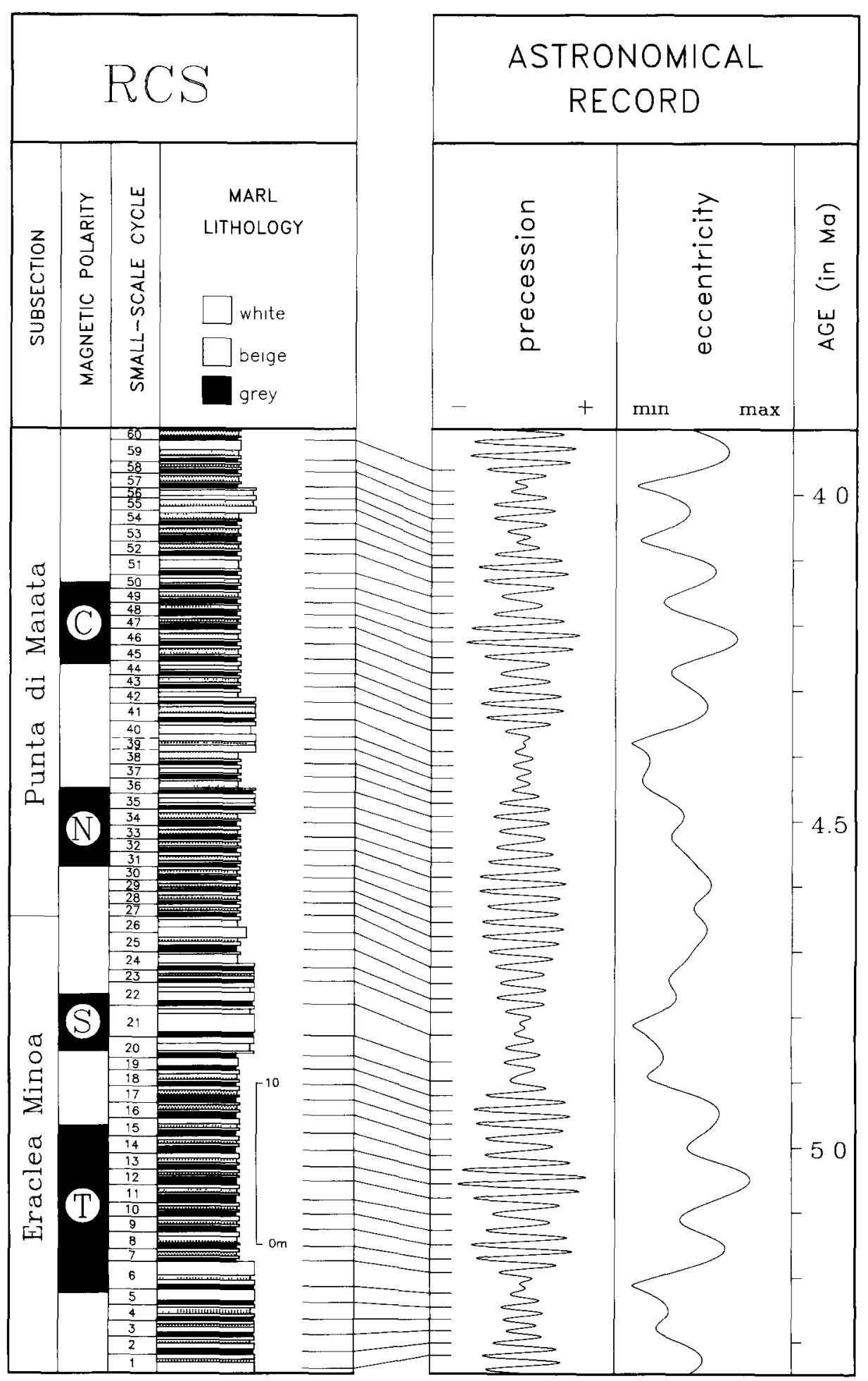

Fig. 4 Correlation of the small-scale cycles 1-60 of the Trubı in the Rossello composite section to the astronomical record based on the astronomical calibration of the larger-scale cycles ( $F_{1 g} 3$ ) and the inferred phase relation with precession See caption to Fig 3 
planation for the observed strong overprint of the 100 ky variations in $\mathrm{CaCO}_{3}$ between 3.2 and 3.7 Ma. This overprint is in perfect agreement with the eccentricity pattern, which displays the most pronounced 100 ky minima in this particular interval. Now that these larger-scale, eccentricity-related $\mathrm{CaCO}_{3}$ cycles have been astronomically calıbrated, the next step is the correlation of the small-scale cycles to the precession record

\section{Caltbratton of small-scale $\mathrm{CaCO}_{3}$ cycles to pre- cession}

\section{Cycles $1-60$}

Using the astronomical calibration of the larger-scale, eccentricity-related $\mathrm{CaCO}_{3}$ cycles as a starting point, the small-scale cycles $1-60$ can be correlated stratghtforwardly to precession (Fig. 4). This correlation implies that the extra-ordinary thick cycles $6,21,22$ and 59 each correlate with two (low amplitude) precession cycles Consequently, these small-scale cycles indeed represent composite cycles, 1.e, cycles which contain an extra cycle that lacks sedımentary expression (note that the composite character of cycle 21 is actually perceptible at Capo Spartıvento in adjacent southern Calabria, because it contains an additional grey marl bed; author's field observations). In addition, cycle 41 should comprise an extra cycle This composite cycle had not been expected on the basis of its thickness. Its presence, however, is not in contradiction with the actual lithologic observations. Cycle 41 constitutes (the major) part of the upper protruding marl bed in a succession of two such beds which combined encompass the small-scale cycles 38-42 and compose the largestscale $400 \mathrm{ky} \mathrm{CaCO}_{3}$ maximum dated at $4.38 \mathrm{Ma}$ (Figs. 3 and 4) The subdivision of such thick beds into individual marl beds of the small-scale cycles is usually complicated by their massive appearance and any attempt in this direction may

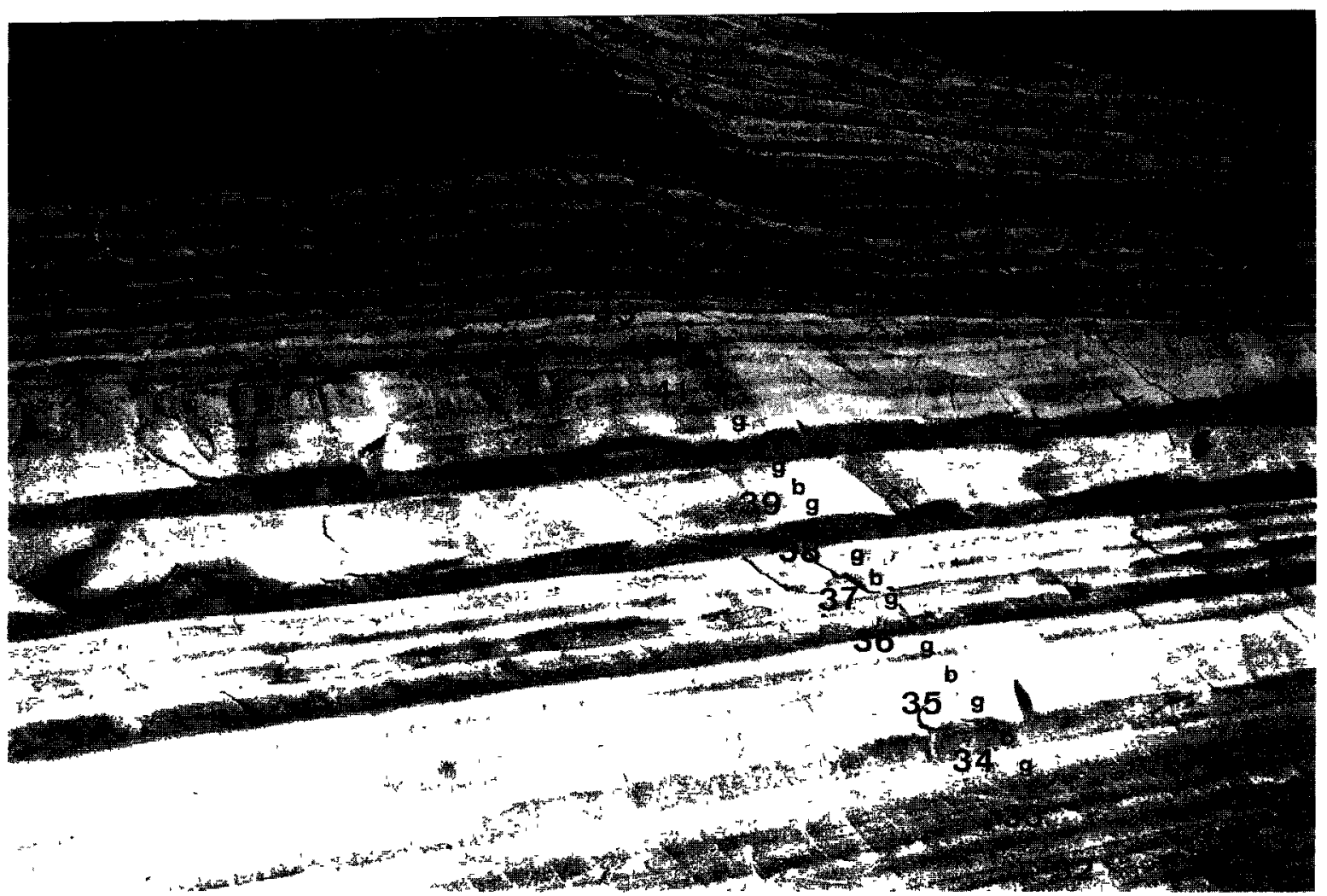

Fig 5 Punta dı Marata The $\mathrm{CaCO}_{3}$ maxımum of the largest-scale, $400 \mathrm{ky}$ cycle which encompasses the small-scale cycles $34-42$ $G$ denotes grey marl layers and $b$ beige marl layers 
therefore be subject to error. In this respect, the interpretation of cycle 41 being a single small-scale cycle of average thickness may not be correct. Close reexamination of the weathering profile of the massive bed containing cycle 41 , provides some evidence for the presence of an extra cycle ( $F_{1} g$ 5). Our probably incorrect first interpretation seems to have originated partly from the fact that the two correlative precession cycles lasted less than two times the average periodicity of a precession cycle (1.e $38 \mathrm{ky}$ ). Consequently, the presence of this extra cycle is less evident from the increase in bed-thickness itself

Such periodicities, which markedly differ from the average duration of a precession cycle, can be held responsible for other (consistent) irregularitıes in the thickness pattern of the small-scale cycles as well From the other small-scale cycles containing an additional cycle, only cycle 21 is almost twice as thick as a single regular cycle, whereas cycles 6,22 and 59 are considerably less thick. Accordingly, the two precession cycles which correlate with cycles 6, 22 and 59 lasted 34, 35 and $32 \mathrm{ky}$, respectively, whereas those corresponding to cycle 21 show a combined duration of $43 \mathrm{ky}$. Evidently, only the latter is two times the average periodicity of precession.

The thicker-than-average cycle 20 , on the other hand, clearly represents a single and not a composite small-scale cycle: this cycle does not contain an extra cycle because its increased thickness is not confined to one of the white marls, as in composite cycles, but is distributed (more) evenly over the individual lithologies. The correlative, single precession cycle shows a corresponding longer-than-average periodicity of $28 \mathrm{ky}$.

An important observation is that the presence of these small-scale cycles with deviant thicknesses remains confıned to $400 \mathrm{ky} \mathrm{CaCO}_{3}$ maxıma, ı.e., they occur at times of $400 \mathrm{ky}$ eccentricity mınıma This observation is consistent with the astronomical theory because, during periods of $400 \mathrm{ky} \mathrm{ec}-$ centricity minıma, the contribution of the dominant 23 ky quasi-period to precession is significantly reduced and less dominant quasi-periods may start to interfere (see also fig. 3 in Imbrie et al. [6]).

\subsection{Cycles $59-110$}

The astronomical calibration of the small-scale cycles 59-110 is less straightforward and some minor discrepancies are present. The most likely correlation is presented in Fig. 6. This correlation starts from the assumption that cycle 59 represents a composite cycle. This is based on the fact that the exceptional thickness of this cycle remains totally confined to the upper white marl bed in this cycle. This implies, however, that the precession cycle with the "prolonged" periodicity of 29 ky at $3.88 \mathrm{Ma}$ does not correspond to the significantly thicker than average cycle 64 , but to cycle 63. Also the relative position of cycles 69 and 99 is not in complete accordance with the precession record (F1g. 6). The grey marl beds in these cycles clearly mark $100 \mathrm{ky} \mathrm{CaCO}_{3}$ maxıma. Accordıng to the established phase relations, these cycles should correlate to minimum amplitude peaks of the precession index to negative values, which result from the eccentricity modulation of precession. The corresponding peaks in the precession record, however, are positioned either one precession cycle too low (in case of cycle 69) or one cycle too high (1n case of cycle 99). The latter also accounts for cycle 104 . In contrast to the preceeding cycle 103 , this cycle contains a very faint, non-laminated sapropelitic layer From the established phase relations, it can be inferred that the grey bed of cycle 103 and not the vague sapropelitic layer of cycle 104 should correlate with the minimum amplitude peak in the precession record (Fig. 6). Finally, our correlation implies that cycle 96 represents a composite cycle although this is not directly evident from the thickness of this cycle (Fig. 6). A second lithologic log obtained durıng the paleomagnetic sampling campaign revealed that this cycle is thicker than our measurements suggest [25]. We refrained from modifyıng our correlation scheme to correct for these small discrepancies because even a slight modification would immediately result in simular discrepancies elsewhere.

A partial explanation for these discrepancies may be found in the problematic logging of the stratıgraphic interval which ranges from cycle 70 to cycle 76 To cover this particular interval, we had to incorporate the somewhat less clearly exposed and therefore less suitable Punta Grande subsection in our Rossello composite. At Lido Rossello, this interval is complicated by tectonic deformation in the uppermost part of the section. Also at Capo Branco it proved impossible to log this interval in a single, continuously exposed and 


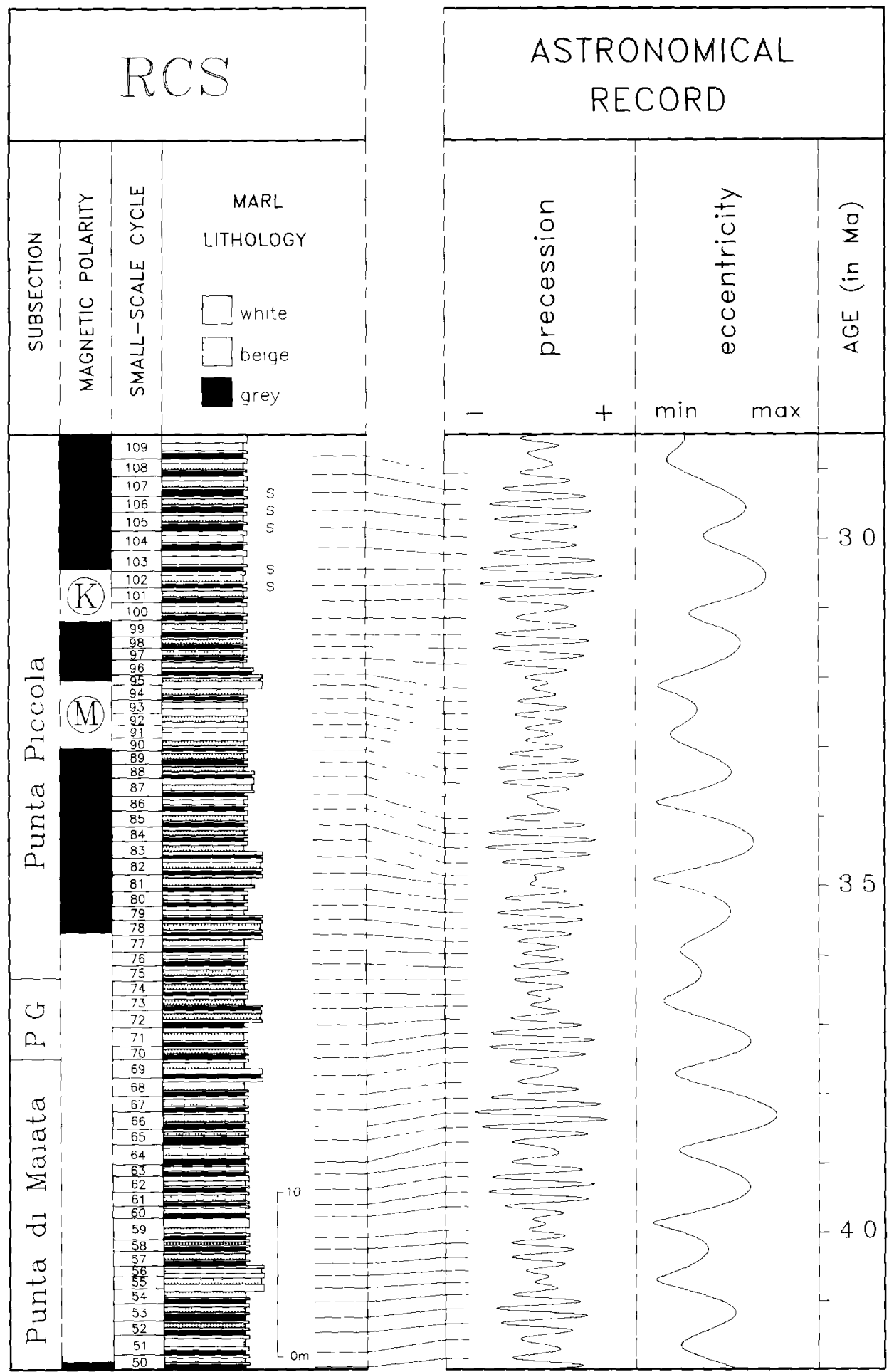

Fig 6 Correlation of the small-scale cycles 50-109 in the Rossello composite section to the astronomical record based on the astronomical calıbration of the larger-scale cycles (Fig 3) and the inferred phase relation with precession See caption to Fig 3. 
undisturbed succession (see also Fig. 2). Despite these stratigraphic problems, an error in the logging, which exceeds one small-scale cycle, can be excluded with certainty.

The astronomical solution offers an alternative explanation for the observed (minor) discrepancies. Although the astronomical record is considered reliable in the time domain over the last 5.0 Ma [21], slight modifications of specific detals can not be ruled out completely. Finally, the applied phase relations may represent a simplification of the actual relationship between the sedimentary and astronomical cycles. For the moment, however, these phase relations do represent a fair and useful approximation.

Summarizing, there is in general a good coherence between the detaled record of $\mathrm{CaCO}_{3}$ cycles and the astronomical record for this interval. This coherence applies in particular to the relative position of $\mathrm{CaCO}_{3}$ maxıma of the largerscale, eccentricity-related cycles with respect to the correspondıng eccentricity minıma in the astronomical record (Fig 3). As far as the precise calibration of the small-scale cycles $59-110$ to precession is concerned, some minor discrepancies remain, but these discrepancies never exceed one cycle.

\subsection{Cycles $110-120$}

A more serıous problem was initially encountered in correlating the uppermost cycles $110-120$ to the astronomical record. A considerable discrepancy with the astronomical record for this interval would cast serious doubt on the correctness of the astronomical calibration of cycles $1-110$ as presented in the previous sections.

In the uppermost part of the Rossello composite section, a succession of six sapropelitic layers can be distınguished comprising the smallscale cycles 114-119 (Fig. 3) At Punta Piccola, these layers actually consist of dark grey coloured marly clays of which only the uppermost three or four can be termed sapropels. This succession composes a very characteristic pattern, which can easily be recognized elsewhere in the Mediterranean and which has been correlated to the precession record [2]. Consequently, these sapropels provide fixed calibration points with the astronomical record.

The five lowermost sapropels in the Rossello composite occur in cycles 102, 103 and 105-107 (Fig. 3) and have been correlated to the astronomical record as well [2]. This correlation actually differs one precession cycle from the presently advocated astronomical calibration (Fig. 6). Initial attempts to extend this new calibration to the calıbrated succession of 6 sapropelitic layers failed due to a substantial lack of small-scale cycles in the interjacent interval (Fig. 3) This discrepancy is only partially reduced if cycles 112 and 113 are considered composite cycles. This assumption is based on the exceptional thickness of these cycles and the fact that they contain a relatively thick and indurated white marl bed (F1g. 3). Unfortunately, a thorough analysis of this interval is strongly hampered by a conspicuous increase in sedimentation rate by a factor of $2-2.5$ deduced from the overall increase in the thickness of the sedimentary cycles (Fig. 3). From this increase in cycle thickness, it can be inferred that the sedimentation rate started to increase between cycles 108 and 110; cycle 109 represents a cycle of intermediate thickness.

An alternative interpretation of this interval is possible, however, and more plausible from our point of view. This alternative implies that the increase in sedimentation rate occurred higher in the succession and that, in addition to cycles 112 and 113 , cycles 110 and 111 contain an extra cycle as well. The intermediate thickness of cycle 109 is then explained by the longer-than-average per1odicity, 1.e. $28 \mathrm{ky}$, of the correlative precession cycle (Fig. 7). According to this interpretation, there is no discrepancy between the number of (small-scale) sedimentary cycles and the number of precession cycles (F1g. 7).

To find supportıng evidence for this interpretatıon, we logged the time-equivalent part of the (Monte) San Nicola section on Sicily (Figs. 1 and 2 ), because it is less affected by an increase in sedimentation rate (Fig. 7). The succession of sedimentary cycles observed in the Punta Piccola subsection of the Rossello composite can easily be recognized at Monte San Nicola and essentially confirms our interpretation (Fig. 7). Cycles 112 and 113 are twice as thick as the overlyıng regular small-scale cycles 114-119 and cycle 110 and, although to a lesser extent, also cycle 111 are considerably thicker than the preceeding smallscale cycles. According to the preferred astronoml- 


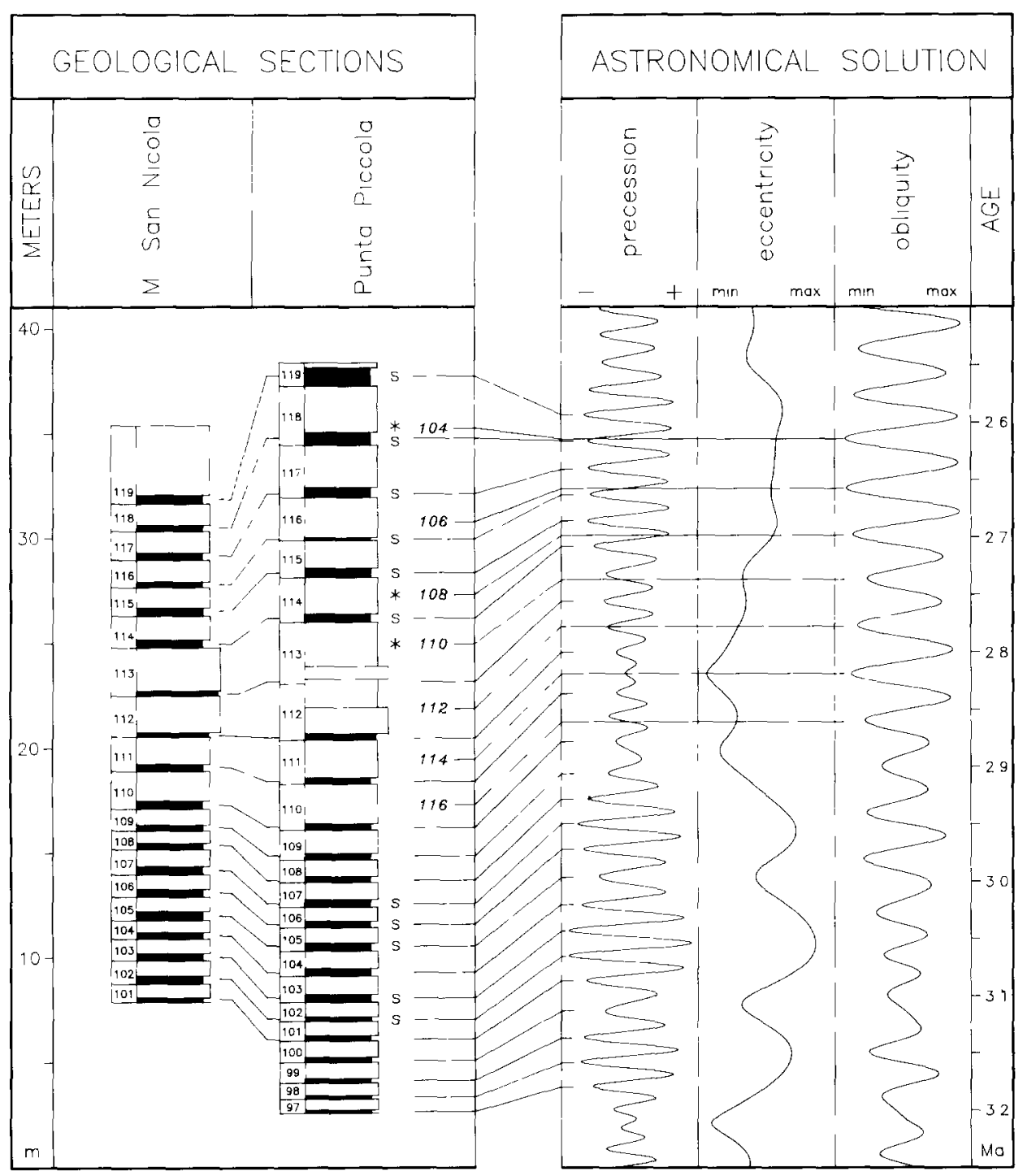

Fig 7 Correlation of the small-scale cycles 97-119 in the Narbone part of the Rossello composite section to precession. Small-scale cycles 110-113 represent composite cycles and correspond to two precession cycles Positions of glacial isotope stages 104 to 110 (based on $[26,28]$ ) as well as the inferred positions of glacial stages 112 to 116 and their correlation to obliquity minıma are also shown (Isotope stages in italics) Associated influxes of $N$ atlantica are marked with an asterisk See caption to Fig 3

cal calibration to precession, the composite cycle 111 has a duration of $35 \mathrm{ky}$ only, whereas the composite cycles 110,112 and 113 lasted 42, 44 and $46 \mathrm{ky}$, respectively.

The most strongly marked increase in sedimentation rate according to this option occurred around the lowermost sapropel of the distinct cluster of six sapropelitic layers in the uppermost part of the Rossello composite section (Fig. 8). This increase coincides with the first influx of
Neogloboquadrina atlantica in the Mediterranean which has been correlated with glacial oxygen 1sotope stage 110 of Raymo et al. [10] (see [28]). Stage 110 represents the oldest glacial in the Pliocene for which extensive ice rafting in the northern Atlantic can be demonstrated on the basis of the colour variation in the DSDP sites from Leg 94 [29]. This coincidence suggests that glacio-eustatic sealevel fall and associated lowering of the base level of erosion invoked the observed in- 


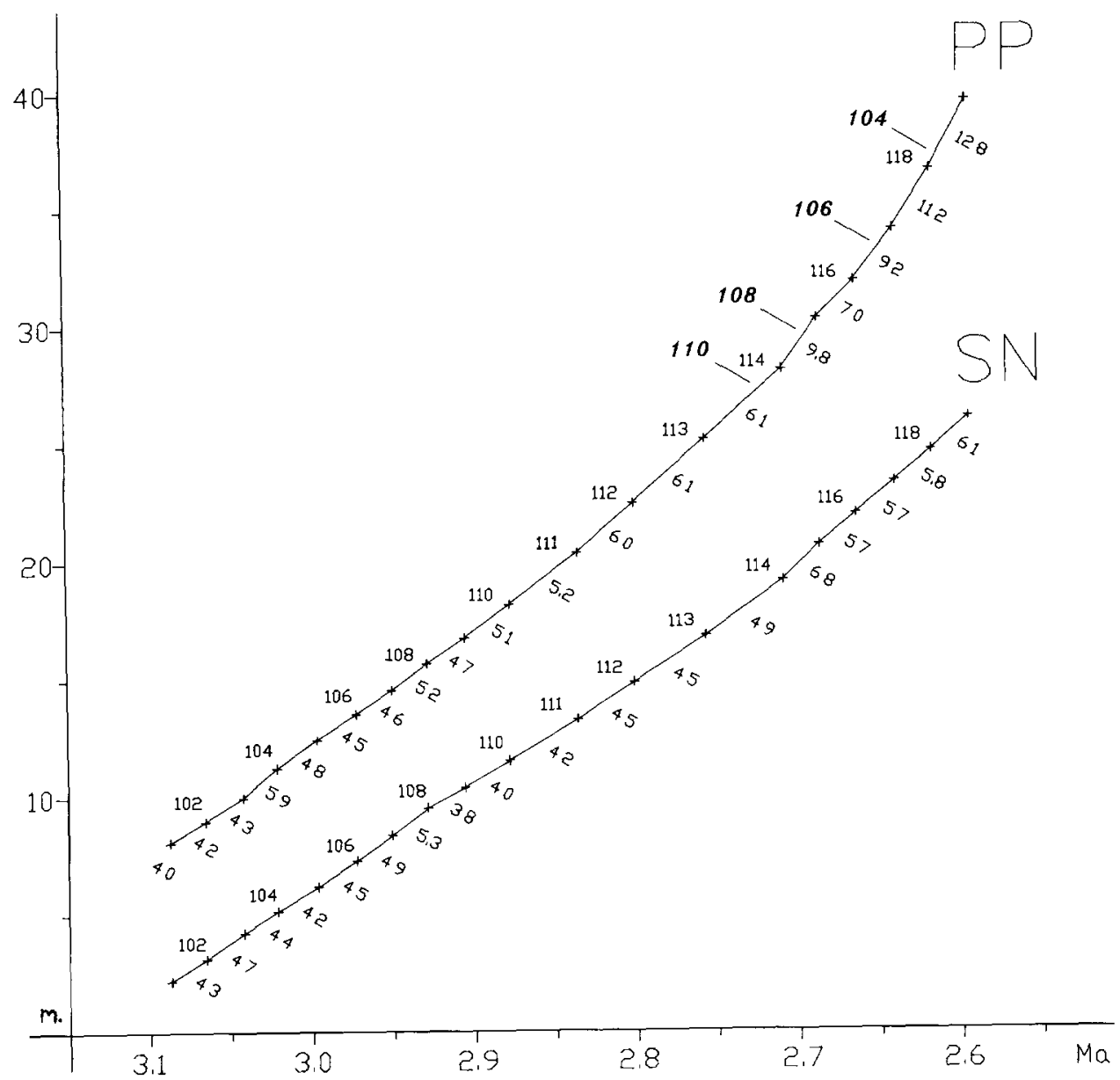

Fig 8 Sediment accumulation diagrams of the Monte San Nicola section and the Punta Piccola subsection of the Rossello composite section, using the astronomical ages of the small-scale cycles Number of the small-scale cycles in the Rossello composite and the sedimentation rate per small-scale cycle are indicated. Also shown is the position of the glacial isotope stages 104 to 110 [26,28]

crease in sedimentation rate. An earliest increase in sedimentation rate is already perceptible in cycles 111-113 at Punta Piccola (Fig. 8). This increase may be related to glacio-eustatic sealevel changes as well. Indications for older (less severe) glacials are found in the isotope and $\mathrm{CaCO}_{3}$ records from DSDP Site 607 ([10]; i.e., stages 112, 114 and 116).

Finally, the stratigraphic position of glacial stages 104 to 110 , as well as the inferred position of stages 112 to 116 , and their correlation to obliquity minima suggest that the composite character of our sedimentary cycles $110-113$ is related to the interference of precession and obliquity. The position of glacial stages 110 to 116 matches the position of the extra small-scale cycles which lack sedımentary expression in the composite cycles. Apparently, obliquity forced glacial periods-corresponding to relative dry climatic condition in the Mediterranean Pliocene (CombourıeuNebout, pers. commun) - counterbalanced the opposite effect exerted by precession minima on Mediterranean climate-corresponding to wet climatic conditions [16-18]-during this time interval. However, this almost perfect interference with precession is not the only factor which contributed to the reflection of obliquity in the sedimentary record. At the same time, the influence of precession itself on climate was strongly reduced due to the low amplitude variations of the precession index connected with the 400 ky eccentricity mınimum at $2.8 \mathrm{Ma}$. 


\section{Results}

\section{Ages of $\mathrm{CaCO}_{3}$ cycles}

With the accurate calibration of the $\mathrm{CaCO}_{3}$ cycles to the astronomical record, ages can be assigned to the individual grey beds of the smallscale cycles. Strictly speaking, a time lag between astronomical forcing, and climate response and deposition of small-scale sedımentary cycles must be taken into account. For the base of the youngest, Holocene sapropel, a tıme lag of 2-3 ky can be inferred from the accurate AMS ${ }^{14} \mathrm{C}$-dating of this lithohorizon at $9 \mathrm{ka}[30,31]$ and the age of $11.5 \mathrm{ka}$ for the correlative precession peak At Punta Piccola and Monte San Nicola, sapropels are intercalated in the basal part of the grey beds. The base of these sapropels, however, is not coincident with the bottom of the grey beds but is usually found somewhat higher $-5-10 \mathrm{~cm}-$ in the succession Consequently, an approxımate time lag of $1 \mathrm{ky}$ can be inferred for the base of the grey beds while a tıme lag of $4 \mathrm{ky}$ can be inferred for the mid-points of these beds, at least if we assume that the sedimentation rate remains constant in the small-scale cycles. The (lagged) ages of the small-scale cycles in the Rossello composite sectıon are presented in Table 1. These ages depend critically on (1) the correctness of the proposed astronomical calibration, and (2) the accuracy of the astronomical solutions. As far as the first point is concerned, this calibration can only be $400 \mathrm{ky}$ or multiples of $400 \mathrm{ky}$ in error, because the largest-scale $400 \mathrm{ky}$ cycle was used for a preliminary first-order calibration of the $\mathrm{CaCO}_{3}$ record to the astronomical (eccentricity) record, preceding the high-resolution correlation of the small-scale $\mathrm{CaCO}_{3}$ cycles to precession. The new astronomical solution seems to be valid over the last $5 \mathrm{Ma}$ in the time domain and over at least the last $10 \mathrm{Ma}$ in the frequency domain [21].

Recently, Hilgen [2] introduced a MPRS (Mediterranean Precession Related Sapropel) coding according to which Pliocene-Pleistocene sapropels are coded after the correlative peak of the precession index numbered from the Recent. In order to incorporate also the small-scale $\mathrm{CaCO}_{3}$ cycles in this coding scheme, we substitute MPRS for MPRC which stands for Mediterranean Precession Related Cycle. The MPRC coding for all small-scale $\mathrm{CaCO}_{3}$ cycles in the Rossello composite has been included in Table 1 as well. It actually refers to the grey beds in the small-scale cycles only. In principle, the beige layers can be included in this coding scheme as well. These layers should correlate with positive peaks of the precession index because they represent the opposite lithology in the small-scale cycles with respect to the grey layers.

\subsection{Ages of broevents}

The astronomical datıng of the $\mathrm{CaCO} 3$ cycles further provides new ages for the planktonic foraminiferal and nannofossil bioevents recorded in the Rossello composite section. These ages have been summarized and compared with the conventional ages in Table 2. The stratigraphic positions of planktonic foraminiferal events are based on Hilgen and Langereis [3], Zachariasse et al $[25,26]$ and Langeress and Hilgen [27]. For the nannofoss1l events, we used the work of Driever [32].

\section{Ages of reversal boundarles}

The astronomical calıbration of the $\mathrm{CaCO}_{3}$ cycles, in addition, provides very accurate ages for the geomagnetic polarity reversals recorded in the Rossello composite section. The stratigraphic positions of these reversals are based on a high-resolution magnetostratigraphy, which showed that almost the complete G1lbert and Gauss Chrons are represented in the Rossello composite [27]. The astronomically calıbrated ages of the reversal boundaries as well as their stratigraphic position with respect to the MPRC-coded $\mathrm{CaCO}_{3}$ cycles are given in Table 3 . In this table, the resulting ages are further compared with the ages for these boundaries according to more conventional time scales. These conventional time scales are either based on $\mathrm{K} / \mathrm{Ar}$ radiometric datıng of volcanic rocks of known polarity $[20,33]$ or on linear interpolation between radiometrically dated magnetostratıgraphic calıbration points in marine magnetic anomaly sequences (e.g. [4,34]). With the present study, the astronomically calibrated (polarity) time scale of Shackleton et al. [1] and Hilgen [2] for the late Pliocene-Pleistocene has been extended to the Miocene/Phocene boundary Consequently, this astronomically calibrated time 
scale covers now the complete Plocene and Pleistocene.

The astronomical calibrated age of $3.58 \mathrm{Ma}$ for the Gilbert/Gauss Chron boundary confirms earlier conclusions that $\mathrm{K} / \mathrm{Ar}$ dating yields ages that are consistently too young $(5-7 \% ;[1,2])$ This is particularly true for the radiometrically more accurately dated Gilbert/Gauss, Gauss/Matuya-

TABLE 1

Cycle number, MPRC-code, age and lagged age of small-scale sedımentary cycles in the Rossello composite section Cycle number in the Rossello composite as numbered from the base of the Trubı upwards MPRC (Mediterranean Precession Related Cycle) codıng and (lagged) age after the correlative peak of precession as numbered from the Recent. Age refers to the age of the precession peak, lagged age to the age of the mid-point of the correlative grey bed in the small-scale cycle

\begin{tabular}{|c|c|c|c|c|c|c|c|c|c|c|c|}
\hline $\begin{array}{c}\text { Rcs } \\
\text { cycle no }\end{array}$ & $\begin{array}{c}\text { MPRC- } \\
\text { code }\end{array}$ & age & $\begin{array}{l}\text { lagged } \\
\text { age }\end{array}$ & $\begin{array}{c}\text { Rcs } \\
\text { cycle no. }\end{array}$ & $\begin{array}{c}\text { MPRC- } \\
\text { code }\end{array}$ & age & $\begin{array}{l}\text { lagged } \\
\text { age }\end{array}$ & $\begin{array}{c}\text { Rcs } \\
\text { cycle no }\end{array}$ & $\begin{array}{c}\text { MPRC- } \\
\text { code }\end{array}$ & age & $\begin{array}{c}\text { lagged } \\
\text { age }\end{array}$ \\
\hline 119 & 250 & 2593 & 2.589 & 79 & 342 & 3.559 & 3.555 & 39 & 426 & 4.434 & 4.430 \\
\hline 118 & 252 & 2.616 & 2612 & 78 & 344 & 3579 & 3.575 & 38 & 428 & 4.452 & 4.448 \\
\hline 117 & 254 & 2639 & 2.635 & 77 & 346 & 3.597 & 3.593 & 37 & 430 & 4.472 & 4.468 \\
\hline 116 & 256 & 2.663 & 2659 & 76 & 348 & 3615 & 3611 & 36 & 432 & 4.493 & 4489 \\
\hline 115 & 258 & 2.686 & 2682 & 75 & 350 & 3.635 & 3631 & 35 & 434 & 4.515 & 4.511 \\
\hline 114 & 260 & 2.708 & 2704 & 74 & 352 & 3.654 & 3.650 & 34 & 436 & 4.540 & 4536 \\
\hline 113 & 264 & 2756 & 2.751 & 73 & 354 & 3672 & 3668 & 33 & 438 & 4.563 & 4559 \\
\hline 112 & 268 & 2.800 & 2.796 & 72 & 356 & 3690 & 3.686 & 32 & 440 & 4.586 & 4582 \\
\hline 111 & 272 & 2.835 & 2831 & 71 & 358 & 3711 & 3707 & 31 & 442 & 4608 & 4.604 \\
\hline 110 & 276 & 2.877 & 2.873 & 70 & 360 & 3.731 & 3.727 & 30 & 444 & 4.631 & 4.627 \\
\hline 109 & 278 & 2905 & 2901 & 69 & 362 & 3753 & 3749 & 29 & 446 & 4.655 & 4.651 \\
\hline 108 & 280 & 2.928 & 2924 & 68 & 364 & 3782 & 3778 & 28 & 448 & 4.677 & 4673 \\
\hline 107 & 282 & 2950 & 2.946 & 67 & 366 & 3804 & 3.800 & 27 & 450 & 4700 & 4.696 \\
\hline 106 & 284 & 2972 & 2.968 & 66 & 368 & 3826 & 3.822 & 26 & 452 & 4723 & 4.719 \\
\hline 105 & 286 & 2.996 & 2.992 & 65 & 370 & 3.847 & 3.843 & 25 & 454 & 4748 & 4.744 \\
\hline 104 & 288 & 3.021 & 3017 & 64 & 372 & 3.869 & 3865 & 24 & 456 & 4770 & 4766 \\
\hline 103 & 290 & 3.042 & 3038 & 63 & 374 & 3897 & 3.893 & 23 & 458 & 4.792 & 4788 \\
\hline 102 & 292 & 3.065 & 3.061 & 62 & 376 & 3.920 & 3916 & 22 & 462 & 4826 & 4822 \\
\hline 101 & 294 & 3.087 & 3.083 & 61 & 378 & 3.941 & 3.937 & 21 & 466 & 4870 & 4866 \\
\hline 100 & 296 & 3113 & 3109 & 60 & 380 & 3962 & 3.958 & 20 & 468 & 4.897 & 4893 \\
\hline 99 & 298 & 3137 & 3133 & 59 & 384 & 3996 & 3.992 & 19 & 470 & 4920 & 4.916 \\
\hline 98 & 300 & 3158 & 3154 & 58 & 386 & 4015 & 4011 & 18 & 472 & 4.942 & 4.938 \\
\hline 97 & 302 & 3179 & 3.175 & 57 & 388 & 4036 & 4.032 & 17 & 474 & 4.964 & 4.960 \\
\hline 96 & 306 & 3.215 & 3.211 & 56 & 390 & 4.057 & 4.053 & 16 & 476 & 4987 & 4.983 \\
\hline 95 & 308 & 3233 & 3229 & 55 & 392 & 4073 & 4069 & 15 & 478 & 5012 & 5.008 \\
\hline 94 & 310 & 3253 & 3249 & 54 & 394 & 4091 & 4087 & 14 & 480 & 5.035 & 5031 \\
\hline 93 & 312 & 3.272 & 3268 & 53 & 396 & 4.112 & 4.108 & 13 & 482 & 5057 & 5.053 \\
\hline 92 & 314 & 3290 & 3.286 & 52 & 398 & 4133 & 4.129 & 12 & 484 & 5.079 & 5.075 \\
\hline 91 & 316 & 3309 & 3.305 & 51 & 400 & 4156 & 4152 & 11 & 486 & 5.102 & 5098 \\
\hline 90 & 318 & 3330 & 3326 & 50 & 402 & 4183 & 4.179 & 10 & 488 & 5.128 & 5.124 \\
\hline 89 & 320 & 3.351 & 3.347 & 49 & 404 & 4.206 & 4.202 & 9 & 490 & 5150 & 5146 \\
\hline 88 & 322 & 3.371 & 3.367 & 48 & 406 & 4.227 & 4.223 & 8 & 492 & 5171 & 5.142 \\
\hline 87 & 326 & 3402 & 3398 & 47 & 408 & 4249 & 4.245 & 7 & 494 & 5.192 & 5.188 \\
\hline 86 & 328 & 3423 & 3419 & 46 & 410 & 4274 & 4.270 & 6 & 498 & 5.226 & 5222 \\
\hline 85 & 330 & 3.445 & 3441 & 45 & 412 & 4.298 & 4294 & 5 & 500 & 5246 & 5.242 \\
\hline 84 & 332 & 3466 & 3462 & 44 & 414 & 4.320 & 4316 & 4 & 502 & 5.266 & 5.262 \\
\hline 83 & 334 & 3486 & 3.482 & 43 & 416 & 4341 & 4.337 & 3 & 504 & 5.283 & 5.279 \\
\hline 82 & 336 & 3.497 & 3493 & 42 & 418 & 4362 & 4358 & 2 & 506 & 5.302 & 5298 \\
\hline 81 & 338 & 3518 & 3.514 & 41 & 422 & 4394 & 4.390 & 1 & 508 & 5.322 & 5.318 \\
\hline 80 & 340 & 3.538 & 3.534 & 40 & 424 & 4414 & 4410 & & & & \\
\hline
\end{tabular}




\section{TABLE 2}

Conventional and new astronomically calibrated age of the main calcareous plankton datum planes (in the Rossello composite section) Also indicated in the position of these datum planes with respect to the MPRC-coded small-scale cycles Uneven (MPRC) numbers refer to beige layers in the smallscale cycles after the correlative peak of the precession index to positive values Position and conventional age of planktonic foraminiferal datum planes based on Langeress and Hilgen [27], and of nannofossi] datum planes on Driever [32]

\begin{tabular}{lll}
\hline Biostratıgraphic datum planes & Old age & $\begin{array}{l}\text { New Cycle } \\
\text { age }\end{array}$ \\
\hline
\end{tabular}

Planktonıc foramınıfera

$N$ atlantica $\quad F O$

$G^{*}$ altispira LO

$S^{*}$ seminulina

$G$ puncticulata

LO

$255^{*}$

$272 \quad 262$

$304-305 \quad 317 \quad 302$

$\begin{array}{lll}304-305 & 317 & 302 \\ 307 & 321 & 304\end{array}$

$G$ crassaformis

$G$ puncticulata

reappearance $\quad 3.15-318 \quad 331 \quad 317$

reappearance $320 \pm 001 \quad 335 \quad 321$

$G$ crassaformis

disappearance

FO

$G$ margaritae

LO

$G$ margartae

$\mathrm{LCO}$

$G$ puncticulata

FO

$G$ margaritae

$\mathrm{FCO}$

Sphaerotdinellopsis top acme

Sphaeroidinellopsis bottom acme

$338 \pm 001 \quad 355 \quad 342$

$340 \pm 001 \quad 358 \quad 345$

$356-359 \quad 379 \quad 365$

$371 \pm 001 \quad 396 \quad 380$

$412-413 \quad 450 \quad 433$

$464+001 \quad 507 \quad 483$

$474 \pm 001 \quad 520 \quad 495$

$483 \pm 001 \quad 529 \quad 505$

Calcareous nannoplankton

$D$ tamalss subtop

$D$ pentaradiatus

Sphenolithus spp

$R$ pseudoumbilica

top paracme

subtop

subtop

351

350

363

$D$ pentaradiatus

bottom

paracme $\quad 366$

$D$ tamalis

subbottom

369

subbottom
359346

369356

$386 \quad 372$

$392 \quad 376$

396380

$410 \quad 394 / 6$

$N=$ Neogloquadrina, $G^{*}=$ Globoquadrina, $S^{*}=$ Sphaeroudinellopsis, $G=$ Globorotalia, $\quad D=$ Discoaster,$\quad R=$ Retıculofenestra

ma and Brunhes/Matuyama Chron boundaries [20]. For polarity reversals older than the Gilbert/ Gauss boundary, both the absolute and relative difference with the most commonly used conventional tıme scale [4] increases with (increasing) age. For the oldest astronomically dated reversal boundary, the lower Thvera, this discrepancy even amounts to $460 \mathrm{ky}$ or $9.5 \%$. The $\mathrm{K} / \mathrm{Ar}$ age of 5.07 $\mathrm{Ma}$ for the Thvera from its type locality on Iceland [33], however, is in good agreement with the age constraints set by the astronomical calibration of the reversal boundaries. This finding is in contradiction with our previous conclusion that $\mathrm{K} / \mathrm{Ar}$ datıng results in systematically younger ages. On

Iceland, such younger ages, however, are found for polarity zones other than the Thvera. These younger ages may result from the diffusional loss of radogenic argon; this process is supposed to underlie the occurrence of anomalously young $\mathrm{K} / \mathrm{Ar}$ ages of lavas in otherwise "continuous" sequences on Iceland [33,35] and it can not be excluded that most if not all samples may have lost variable amounts of radiogenic argon [35]. For instance six out of 23 datings in the study of McDougall et al. [33] are demonstrably too young with respect to their stratigraphic position Nevertheless, only the most obvious one out of four was excluded from the 17-point age data set they employed to construct their polarity time scale on the basis of a linear regression analysis.

This implies that the oldest $\mathrm{K} / \mathrm{Ar}$ age for a certain polarity event may approach its true age better than the average $\mathrm{K} / \mathrm{Ar}$ age. Supportive evidence for this conclusion is provided by the radıometric ages which are presently available for the Reunion. The oldest $\mathrm{K} / \mathrm{Ar}$ age (2.14 ka; [36]) is remarkably consistent with the astronomically calibrated age of 2 14-2 15 Ma for this event [2], whereas the younger ages, even if obtained from (apparently) the same event on Reunion island, are evidently not This spread in ages has even led to the supposition of the existence of a second Reunion event [37]. Similarly, the oldest ages for the Jaramillo and Cobb Mountain normal polarity events may be in line with the astronomically calibrated ages but, in these cases, it is uncertain whether the samples actually belong to these events because they were not obtained from a well established polarity sequence $[20,36,38-40]$. Moreover, serious doubt on the correctness of the conventional age of $073 \mathrm{Ma}$ for the Brunhes/Matuyama boundary has recently been expressed on the basis of new radiometric datıngs $[41,42]$. Except for the Brunhes/Matuyama, this still does not provide a satisfactory explanation for the observed discrepancy between the radiometric and astronomically calibrated ages of the major (chron) boundaries and the fact that this discrepancy is proportionately constant This proportional constancy initially provided the reasonable argument to suggest that the discrepancy might be explained by a systematic error in the $\mathrm{K} / \mathrm{Ar}$ radiometric dating method, more specifically in the accuracy of the decay constants [1,2]. This, however, is 


\section{TABLE 3}

Comparison of conventional and astronomically calıbrated ages of Pliocene-Pleistocene geomagnetic polanty reversals. Also indicated is the position of the reversals with respect to the MPRC-coding of the small-scale cycles Uneven numbers refer to beige layers in the small-scale cycles after the correlative peak of the precession index to positive values Between brackets in the last column is the cycle number in the Rossello composite/the sapropel coding after Verhallen [47] $\mathrm{M} \& \mathrm{D}=[20], \mathrm{McD}=[48], \mathrm{Ber}=[4]$, Har $=[34]$, Sha $=[1]$, Hil $=[2]$

\begin{tabular}{|c|c|c|c|c|c|c|c|c|}
\hline \multirow[t]{2}{*}{ Reversal boundary } & \multicolumn{2}{|c|}{$\mathrm{K} /$ Ar dated } & \multicolumn{2}{|c|}{ Seafloor anomaly } & \multicolumn{3}{|c|}{ Astronomically calıbrated } & \multirow{2}{*}{$\begin{array}{l}\text { MPRC } \\
\text { position }\end{array}$} \\
\hline & $\begin{array}{l}\text { M\&D, } \\
1979\end{array}$ & $\begin{array}{l}\mathrm{McD}, \\
1982\end{array}$ & $\begin{array}{l}\text { Ber., } \\
1985\end{array}$ & $\begin{array}{l}\text { Har, } \\
1989\end{array}$ & $\begin{array}{l}\text { Sha, } \\
1990\end{array}$ & $\begin{array}{l}\mathrm{H}_{11}, \\
1991\end{array}$ & $\begin{array}{l}\text { This } \\
\text { paper }\end{array}$ & \\
\hline Brunhes/Matuyama & 073 & 072 & 073 & 0.72 & 078 & & & \\
\hline Jaramillo top & 090 & 089 & 0.92 & 091 & 099 & & & \\
\hline Jaramillo bottom & 097 & 094 & 098 & 097 & 107 & & & \\
\hline Cobb Mountaın & - & - & 110 & - & 119 & & & \\
\hline Olduvat top & 167 & 176 & 166 & 165 & 1.77 & 179 & & 174 \\
\hline Olduvar bottom & 187 & 191 & 188 & 188 & 1.95 & 195 & & $188(\mathrm{C} 1)$ \\
\hline Reunion 1 top & 2.01 & 207 & - & 206 & - & 214 & & 208 (B5) \\
\hline Reunion 1 bottom & 2.04 & 207 & - & 209 & - & 215 & & $208(\mathrm{~B} 5)$ \\
\hline Reunion 2 top & 212 & - & - & - & - & - & & \\
\hline Reunion 2 bottom & 214 & - & - & - & - & - & & \\
\hline Gauss/Matuyama & 248 & 247 & 247 & 245 & 260 & $259 / 262$ & & $250 / 252$ (A5) \\
\hline Kaena top & 292 & 291 & 292 & 291 & & 302 & 304 & $290(103)$ \\
\hline Kaena bottom & 301 & 300 & 299 & 298 & & {$\left[\begin{array}{ll}3 & 08\end{array}\right]$} & 311 & $296(100)$ \\
\hline Mammoth top & 305 & 307 & 308 & 307 & & {$\left[\begin{array}{ll}3 & 20\end{array}\right]$} & 322 & $308(95)$ \\
\hline Mammoth bottom & 315 & 317 & 318 & 317 & & {$\left[\begin{array}{ll}3 & 32\end{array}\right]$} & 3.33 & $318(90)$ \\
\hline Glbert/Gauss & 340 & 341 & 340 & 340 & & {$\left[\begin{array}{ll}358 & 58\end{array}\right.$} & 358 & $344(78)$ \\
\hline Cochitı top & 380 & 3.82 & 388 & 387 & & {$\left[\begin{array}{ll}4 & 22]\end{array}\right.$} & 418 & $402(50)$ \\
\hline Cochitı bottom & 390 & 3.92 & 397 & 399 & & {$\left[\begin{array}{ll}4 & 34\end{array}\right]$} & 429 & $412(45)$ \\
\hline Nunıvak top & 405 & 407 & 410 & 412 & & {$[452]$} & 448 & $434(35)$ \\
\hline Nunivak bottom & 420 & 425 & 4.24 & 4.26 & & {$[4.64]$} & 462 & $444(30)$ \\
\hline Sidufjall top & 432 & 444 & 440 & 441 & & [4.84] & 480 & $462(22)$ \\
\hline Sıdufjall bottom & 447 & 457 & 447 & 448 & & [4 92] & 489 & $468(20)$ \\
\hline Thvera top & 485 & 472 & 457 & 479 & & {$\left[\begin{array}{ll}5 & 02\end{array}\right]$} & 498 & $476(16)$ \\
\hline Thvera bottom & 5.00 & 494 & 477 & 508 & & {$\left[\begin{array}{ll}5 & 26\end{array}\right]$} & 523 & $500(5)$ \\
\hline
\end{tabular}

difficult to reconcile with the $\mathrm{K} / \mathrm{Ar}$ datings, discussed above, which are in complete agreement with the astronomically calibrated ages. Such a large error in the decay constants is also difficult to reconcile with the supposed accuracy of these constants on the order of $0.5 \%$ [43].

\subsection{Age of the Mocene / Plocene boundary}

Finally, the astronomical calibration of the Trubi marls provides a new age for the Miocene/ Pliocene boundary. These marls were deposited in an open, deep marine environment after the Messinian salınity crisis had suddenly come to an end. The base of the Trub1 marls at Capo Rossello, therefore, has been taken to define the Miocene/ Pliocene boundary [44].
Only recently, magnetostratıgraphic age cal1bration (using the conventional tıme scale of Berggren et al. [4]) allowed the assessment of the age of the Miocene/Pliocene boundary by linear extrapolation of sediment accumulation rate or (small-scale) cycle duration $[3,45,46]$. Ages for the Miocene/Pliocene boundary, based on the latter procedure, range from 4.86 [3] to $4.93 \mathrm{Ma}$ [46]. These ages are considerably younger than the traditional age of $5.3 \mathrm{Ma}$ [4]. The latter age was based on long-distance biostratigraphic correlatıons to magnetostratigraphically dated extraMediterranean sequences. The new astronomically calibrated age of $5.32 \mathrm{Ma}$ paradoxically implies a rehabilitation of the traditional age which at that time was based on correlation to a somewhat older stratigraphic level. 


\section{Conclusions}

$\mathrm{CaCO}_{3}$ cycles in the Rossello composite section can be calıbrated accurately to the astronomical record using inferred phase relations between these $\mathrm{CaCO}_{3}$ cycles and astronomical precession and eccentricity in combination with fixed astronomical calibration points provided by the sapropelitic layers in the upper part of the section. A Mediterranean Precession Related Cycle code is assigned to the grey beds in the small-scale $\mathrm{CaCO}_{3}$ cycles after the correlative peak of the precession index numbered from the Recent. This correlation allows all cycles to be dated with an accuracy of approxımately $1 \mathrm{ky}$.

The high-resolution magnetostratigraphy for the Rossello composite section further allows the construction of an astronomically calibrated Geomagnetic Polarity Time Scale with ages for the reversal boundaries of the Kaena (3.04-3.11 Ma) and Mammoth (3.22-3.33 Ma), the Gilbert/Gauss Chron boundary $(3.58 \mathrm{Ma})$, and the reversal boundaries of the Cochitı (4.18-4.29 Ma), Nun1vak (4.48-4.62 Ma), Sidufjall (4.80-4.89 Ma) and Thvera (4.98-5.23 Ma). The age of the Miocene/ Pliocene boundary, as currently defined at the base of the Trubi, is $5.32 \mathrm{Ma}$. New ages have also been assigned for early to early late Plocene planktonic foraminiferal and nannofossil datum planes in the Mediterranean.

This discrepancy between astronomically calıbrated and radıometric age assignments is proportionately constant for the radiometrically most accurately dated geomagnetic polarity reversals, 1.e, the Gilbert/Gauss, Gauss/Matuyama and Brunhes/Matuyama Chron boundaries [20]. This suggests that a systematic error in the decay constants used in K/Ar dating is responsible for the observed discrepancies This conclusion, however, is not confırmed by $\mathrm{K} / \mathrm{Ar}$ ages for a number of polarity events which are consistent with the astronomically calibrated ages. In these cases, the oldest $\mathrm{K} / \mathrm{Ar}$ ages provide the most accurate age estimate suggesting that the diffusional loss of radiogenic argon has a more pronounced and "widespread" influence on the accuracy of $\mathrm{K} / \mathrm{Ar}$ datıngs than previously assumed. Also in view of the assumed accuracy of $0.5 \%$ of the decay constants [43], argon loss provides a far more plaus1ble explanation to account for the observed age discrepancies between the astronomically calibrated and conventional time scales.

\section{Acknowledgements}

C.G. Langereıs and W.J Zachariasse critıcally read earlier versions of the manuscript. The reviews of W.F. Ruddiman, C. Laj and an anonymous reviewer are gratefully acknowledged. This study was funded by the Netherlands Organization for Scientific Research.

\section{References}

1 N J Shackleton, A. Berger and W.R Peltıer, An alternatıve astronomical calıbration of the Lower Pleistocene tıme scale based on ODP Site 677, Trans R Soc Edınburgh 81, $251-261,1990$

2 F J Hilgen, Astronomical calibration of Gauss to Matuyama sapropels in the Mediterranean and implication for the Geomagnetic Polarity Time Scale, Earth Planet Scı Lett 104, 226-244, 1991

3 F J. Hilgen and C G Langereıs, The age of the MıocenePliocene boundary in the Capo Rossello area, Earth Planet Sc1 Lett 91, 214-222, 1988

4 W A Berggren, D V Kent, J J Flynn and J A Van Couvering, Cenozolc geochronology, Geol Soc Am Bull 96, 1407-1418, 1985

5 J D Hays, J Imbrie and N J Shackleton, Varnations in the earth's orbit Pacemaker of the ice ages, Science 194, 11211132,1976

$6 \mathrm{~J}$ Imbrie, J.D. Hays, D G Martınson, A McIntyre, A C Mix, J J Morley, N G Pisıas, W L Prell and N.J Shackleton, The orbital theory of Pleistocene climate Support from a revised chronology of the marine $\delta^{18} \mathrm{O}$ record, in Milankovitch and Clımate, A L Berger et al, eds, NATO ASI Ser C, 126, pp. 269-305, Reidel, Dordrecht, 1984

7 D G Martinson, NG Pisias, J D Hays, J Imbrie, T C Moore and N J Shackleton, Age dating and the orbital theory of the ice ages Development of a high-resolution 0 to 300,000-year chronostratigraphy, Quat Res 27, 1-29, 1987

8 NG Pisias and T C Moore, The evolution of Pleistocene climate' A tıme series approach, Earth Planet Scı Lett 52, 450-458, 1981

9 W F Ruddıman, M.E Raymo, D G Martınson, B M. Clement and J Backman, Plesstocene evolution northern Hemisphere ice sheets and north Atlantic Ocean, Paleoceanography 4, 353-412, 1989

10 M E. Raymo, W F Ruddıman, J Backman, B M Clement and DG Martinson, Late Pliocene variation in northern Hemisphere ice sheets and North Atlantic deep water circulation, Paleoceanography 4, 413-446, 1989

11 R B Kidd, M B Cita and W B.F. Ryan, Stratigraphy of eastern Mediterranean sapropel sequences recovered during DSDP Leg 42A and their paleoenvironmental significance, Init Reps D S D 4 42A, 421-443, U S Gov Print Off, Washington, D C., 1978 
12 E Olausson, Description of sediment from the Mediterranean and Red Sea, Rep Swed Deep-Sea Exped 19471948 8, 337-391, 1961

13 F J Hilgen, Sedimentary rhythms and high-resolution chronostratigraphic correlations in the Mediterranean Pliocene, Newsl Stratıgr 17, 109-127. 1987

$14 \mathrm{~F} \mathrm{~J}$ Hilgen and $\mathrm{CG}$ Langerers, Periodicities of $\mathrm{CaCO}_{3}$ cycles in the Mediterranean Pliocene Discrepancies with the quasi-periods of the Earth's orbital cycles?, Terra Nova $1,409-415,1989$

$15 \mathrm{~J} P$ de Visser, J H J Ebbing, L Gudjonsson, F J Hilgen, F J Jorissen, P J J M Verhallen and D Zevenboom, The origin of the rhythmic bedding in the Plocene Trubi of Sicily, southern Italy, Palaeogeogr, Palaeoclimat, Palaeoecol 69, 45-66, 1989

$16 \mathrm{M}$ Rossignol-Strick, African monsoons, an immediate climatic response to orbital insolation, Nature 303, 46-49, 1983

17 M Rossignol-Strick, Rainy periods and bottom water stagnation mituatıng brine accumulation and metal concentrations 1 The Late Quaternary, Paleoceanography 2, $333-360,1987$

18 E Rohlıng and F J Hilgen, The eastern Mediterranean climate at tımes of sapropel formation a review, Geol Mıjnbouw, 70, 253-264, 1991

19 A L. Berger, Accuracy and frequency stabiltty of the Earth's orbital elements during the Quaternary, in - Milankovitch and Climate, A L Berger et al, eds, NATO ASI Ser C 126, pp 3-39, Reidel, Dordrecht, 1984

20 E A Mankınen and G B Dalrymple, Revised geomagnetıc polarity time scale for the interval $0-5 \mathrm{~m}$ y $\mathrm{B} P$, J Geophys Res 84, 615-626, 1979

21 A Berger and M.F Loutre, Insolation values for the climate of the last $10 \mathrm{~m} \mathrm{y}$, Quat $\mathrm{Scl}$ Rev in press, 1991.

22 M B Cita and S Gartner, Studı sul Plıcene e suglı stratı del passagio dal Miocene al Pliocene, IV The stratotype Zanclean Foramıniferal and nannofossıl biostratıgraphy, Rıv Ital Paleontol Stratıgr 79, 503-558, 1973

$23 \mathrm{P}$ Spaak, Accuracy in correlation and ecological aspects of the planktonic foramıniferal zonation of the Mediterranean Pliocene, Utrecht Micropaleontol Bull 28, 1-160,1983

24 D R $10, \mathrm{R}$ Sprovierı and I Raff 1 , Calcareous plankton biostratıgraphy and biochronology of the Plocene-Lower Pleistocene succession of the Capo Rossello area, Sicily, Mar Micropaleontol 9, 135-180, 1984

25 W J Zachariasse, W J, J D A Zijderveld, C G Langereıs, F J Hilgen and P J J M. Verhallen, Early Late Pliocene biochronology and surface water temperature variations in the Mediterranean, Mar Micropaleontol 14, 339-355, 1989

26 W J Zachariasse, L Gudjonsson, F J Hilgen, C G Langeress, L.J Lourens, P J J.M Verhallen and J.D A Z Z1derveld, Late Gauss to early Matuyama invasions of Neogloboquadrina atlantica in the Mediterranean and associated record of climatic change, Paleoceanography 5, 239-252, 1990

27 C G Langereis and F.J Hilgen, The Rossello composite A Mediterranean and global reference section for the Early to early Late Plocene, Earth Planet Scı Lett 104, 211-225, 1991

28 L J Lourens, F J Hilgen and W J. Zachanasse, Late Plio-
cene-Early Pleistocene astronomically forced sea surface temperature and productivity vanations in the Mediterranean, Mar Micropaleontol in press

29 W F Ruddıman, R.B Kıdd, E Thomas, et al, Inıt Reps D S D P., 94, U S. Gov Print Off Washington, D C, 1987

30 F J Jorıssen, K. van der Borg, A.M Borsettı, L Gudjonsson, F J. Hilgen, S Iaccanno, A F M de Jong, E.J Rohlıng, J.P de Visser and W.J Zacharıasse, Late Quaternary high-resolution biochronology for the central Mediterranean, Mar Micropaleontol in press

31 S R Troelstra, G M Ganssen and G T Klaver, High-resolution analysis of eastern Mediterranean sapropel S1 Chronostratıgraphy, oxygen isotopes and geochemistry, IX RCMNS Congress, Barcelona, Abstr, 349, 1990

32 B W M Driever, Calcareous nannofossil biostratıgraphy and paleoenvironmental interpretation of the Mediterranean Pliocene, Utrecht Micropaleontol Bull 36, 245, 1988

33 I McDougall, K Saemundsson, H Johannesson, N D Watkıns and L Kristjansson, Extension of the geomagnetic polanty tıme scale to $65 \mathrm{~m} \mathrm{y} \mathrm{K}$-Ar datıng, geological and paleomagnetic study of a 3,550-m lava succession in western Iceland, Geol Soc Am Bull 88 1-15, 1977

34 W B Harland, R L Armstrong, A V Cox, L E Cratg, A G Smuth and D G Smith, A Geologic Time Scale 1989, Cambridge Unıv Press, Cambridge, 1989

35 N D Watkıns, L Kristjansson and I McDougall, A detalled paleomagnetic survey of the type location for the Gilsa geomagnetic polarity event, Earth Planet Sci Lett 27, 436-444, 1975

36 I McDougall and $\mathrm{F} \mathrm{H}$ Chamalaun, Geomagnetıc polarity scale of tıme, Nature, 212, 1415-1418, 1966

37 C S Gromme and R L Hay, Geomagnetıc polarity epochs Age and duration of the Olduvar normal polanty event, Earth Planet. Scı Lett 10, 179-185, 1971

38 A Abdel-Monem, N D Watkıns and P W Gast, Potassium-argon ages, volcanic stratıgraphy, and geomagnetıc polanty history of the Canary Islands Tenerife, La Palma, and Hierro, Am J Sc1 272, 805-825, 1972

39 R J Fleck, J H Mercer, A E M Nairn and D.N Peterson, Chronology of late Pliocene and early Pleistocene glacial and magnetic events in southern Argentına, Earth Plan Sc1 Lett 16, 15-22, 1972

40 N D Watkıns and A Abdel-Monem, Detectıon of the Gilsa geomagnetıc polarity event on the Island of Madeira, Geol Soc Am Bull. 82, 191-198, 1971

41 G.A Izett, J D Obradovitch and $\mathrm{H} \mathrm{H}$ Mehnert, The B1shop ash bed (Middle Pleistocene) and some older (Pliocene and Pleistocene) chemically and mineralogically ash beds in Calıfornia, Nevada and Utah, U S Geol Surv Bull. 1675,37 pp , 1988

42 A K Baks1 and E Farrar, A prelımınary attempt at $40 \mathrm{Ar} / 39 \mathrm{Ar}$ dating of lavas spanning the BrunhesMatuyama geomagnetic polarity transition, EOS 71, 1296, 1990

43 N H Gale, The physical decay constants, in Numerical datıng in stratıgraphy, G S Odın, ed, Wiley-Interscience, Chuchester, 107-122, 1982

44 M B Cita, The Miocene/Pliocene boundary history and definition, in Late Neogene Epoch Boundaries, $T$ Saito 
and L.H Burcle, eds, Micropaleontology, Spec Publ 1 , 1-30, 1975

45 J D A. Zıjderveld, W.J Zachariasse, P.J J M Verhallen and F J Hilgen, The age of the Miocene-Pliocene boundary, Newsl. Stratıgr 16, 169-181, 1986

46 J E T Channell, D Rio and R C Thunell, Mrocene/ Plocene boundary magnetostratigraphy at Capo Spartıvento, Calabria, Italy, Geology 16, 1096-1099, 1988
47 P J J M. Verhallen, Early development of Bulımina marginata in relation to paleoenvironmental changes in the Mediterranean, Proc Ned Akad Wet, Ser B 90, 161-180, 1987.

48 I McDougall, The present status of the Geomagnetic Polarity Time Scale, in The Earth, Its origin, structure and evolution, M W McElhinney, ed., pp 543-565, Academic Press, London, 1979 